\title{
Work locus of control and sense of coherence as antecedents of job insecurity
}

\author{
J. Pienaar ${ }^{a \star}$ and H. De Witte \\ ${ }^{a}$ WorkWell Research Unit for Economic and Management Sciences, \\ North-West University, Private Bag X6001, Potchefstroom, 2520, South Africa \\ ${ }^{b}$ Research Group Work, Organisational \& Personnel Psychology WOPP - O2L, \\ Faculty of Psychology \& Educational Sciences - KU Leuven, Leuven, Belgium, \\ and Optentia Research Focus Area, North-West University, Vaal triangle campus \\ *To whom all correspondence should be addressed \\ Jaco.Pienaar@umu.se
}

\begin{abstract}
Previous research has highlighted various antecedents of job insecurity, both in cross-sectional research and in a recent meta-analysis. A review of this literature indicates that work locus of control actually is the only personality antecedent that has received considerable attention, while sense of coherence may also be an important factor to consider. Data on biographical variables, cognitive and affective job insecurity, work locus of control and sense of coherence were gathered from employees across 3 organisations $(\mathrm{N}=718)$, presenting two different sectors (chemical industry and financial services), by means of anonymous surveys. Data were analysed by means of correlations and regression analyses. Results indicate that both work locus of control and sense of coherence play a role in predicting job insecurity, even after controlling for biographical variables. Considering their individual contributions, it is suggested here that sense of coherence may be even more important than work locus of control as a personality antecedent of job insecurity.
\end{abstract}

\section{Introduction}

A review of the job insecurity literature reveals that, mostly, job insecurity has been studied as an antecedent to employee health and well-being. This has also been highlighted by 2 meta-analyses (Cheng \& Chan, 2008; Sverke, Hellgren, \& Näswall, 2002), confirming the detrimental effect of job insecurity on employee health and well-being.

Recently, however, a meta-analysis of the antecedents of job insecurity has also appeared (Keim, Landis, Price, \& Earnest, 2014). What the latter study highlighted is that especially with regard to personality antecedents, it is only locus of control that has received considerable empirical attention. The seminal job insecurity theoretical article of Greenhalgh and Rosenblatt (1984) first posited locus of control as an individual-level personality difference that may act as a moderator of perceptions and reactions to job insecurity.

Other important personality variables have been identified that may affect an employee's perceptions or emotions regarding their probability for becoming unemployed. Sense of coherence (Antonovsky, 1987, 1993), viewed from the salutogenic paradigm, may present as such a variable. Roskies, Louis-Guerin and Fournier (1993) have shown that individuals with higher scores on sense of coherence perceived less risk of job insecurity. However, the issue has apparently received little further attention.

Greenhalg and Rosenblatt (2010) have specifically highlighted sense of coherence as another possible personality antecedent of job insecurity. This paper set out to investigate the role of both a well-known (work locus of control), and less well-known personality antecedent (sense of coherence) of job insecurity across various samples from South Africa's working populace. What could be of particular interest is to also investigate how sense of coherence compares to locus of control in the prediction of job insecurity (i.e. Which of these personality factors matter more?). The context of the study seems particularly relevant, as literature suggests job insecurity in South Africa is increasing (Bezuidenhout, Khunou, Mosoetsa, Sutherland, \& Thoburn, 2007; Forrest, 2014; Kritzinger, Barrientos, \& Rossouw, 2004), and contributing to the emigration of skills and talent (Kerr-Phillips, \& Thomas, 2009).

\section{Overview: General and personality antecedents of job insecurity}

Conceptually, the antecedents of job insecurity are seen as being on the individual, organisational and environmental levels (De Witte, 2005; Greenlagh \& Rosenblatt, 1984; Kinnunen, Mauno, Nätti \& Happonen, 1999; Kinnunen \& Nätti, 1994). Perceptions of job insecurity are informed by i) personality characteristics, such as an external locus of control (Keim, Landis, Price, \& Earnest, 2014) or a low sense of coherence (Roskies et al., 1993), ii) characteristics of the individual and her/his position, including role conflict (Ameen, Jackson, Pasewark, \& Strawser, 1995) and role ambiguity (Ameen et al., 1995, Ashford, Lee, \& Bobko, 1989), and iii) organisational and environmental factors, such as organisational change (Keim et al., 2014). For purposes of this paper, our focus falls specifically on the individual level. 
In terms of the individual or positional antecedents, authors have indicated that type of contract (i.e. permanent vs temporary) is important (Blackmore \& Kuntz, 2011; De Witte \& Näswall, 2003), but also that so-called blue-collar and lower-skilled individuals feel more insecure, at least in European samples (De Witte \& Näswall, 2003). Regarding biographical antecedents, Kinnunen and Nätti (1994) found perceived unemployment risk to correlate with gender, age, and level of education. Låstad, Berntson, Näswall and Sverke (2014) showed age to correlate with qualitative job insecurity, while Kinnunen et al. (1999) also suggest that men experience higher job insecurity than women. In terms of the outcomes of job insecurity, age has been shown to be significant, in that older employees are worse affected (Cheng \& Chan, 2008). If age could act to influence the outcomes of job insecurity, it may also be reasonable to expect that it could affect the perception thereof. In contrast, the meta-analytic results of Keim et al. (2014) show no effects for gender, age and education. As results regarding gender, age, and education are not equivocal, we opted to control for these variables in our analyses.

Debus, König and Kleinmann (2014) note that among antecedents of job insecurity, personality has received the least attention. Personality variables are however important, as they influence individuals' perception and reaction to the external world generally (Näswall, Sverke, \& Hellgren, 2005), the appraisal of stressors specifically (Spector, Zapf, Chen, \& Frese, 2000), and job insecurity particularly (De Witte, 2005; Kinnunen, Feldt, \& Mauno, 2003). Kinnunen et al. (2003) have illustrated a reciprocal relation between selfefficacy and job insecurity. Whereas the experience of job insecurity may work to undermine individuals' efficacy beliefs, those with weaker efficacy beliefs may also be more prone to perceive their positions as being insecure. Lee, Bobko and Chen (2006) have also shown organisationally based self-esteem to relate negatively to job insecurity. Recently, Låstad et al. (2014) illustrated that core selfevaluations had a direct negative relation to both qualitative and quantitative dimensions of job insecurity. Meta-analytic results confirm that an internal locus of control relates to lower job insecurity (Keim et al., 2014).

Spector (1988) extended locus of control research by developing a work domain-specific measure of locus of control, referring specifically to relationships and behaviours at work. It has been defined as 'the belief that rewards and outcomes relating to employment (e.g. salary, promotions) are controlled by an individual's own actions (Internal) or by other forces (External) outside of the individual's influence' (Spector, 1988, in Levy, Cober, \& Norris-Watts, 2004; 140). While developing this scale it was illustrated that the domainspecific measure had stronger relations with organisational variables, than with the general locus of control scale (Rotter, 1966). This result has been confirmed by a meta-analysis (Wang, Bowling \& Eschleman, 2010), longitudinal (Tong \& Wang, 2012) and cross-sectional work (Maram \& Miller, 1998).

Sense of coherence is defined (Antonovsky, 1987; 19) as 'a global orientation that expresses the extent to which one has a pervasive, enduring, though dynamic feeling of confidence that (1) the stimuli deriving from one's internal and external environments in the course of living are structured, predictable, and explicable (comprehensibility); (2) the resources are available to one to meet the demands posed by the stimuli (manageability); and (3) these demands are challenges worthy of investment and engagement (meaningfulness)'. Sense of coherence has been termed a broad individual attribute that influences individuals' perceptions as well as interpretations of events (Johnston, de Bruin, Györkös, Geldenhuys, Massoudi, \& Rossier, 2013). It has a motivational aspect, such as acquiring resources (Feldt, Kivimäki, Rantala \& Tolvanen, 2004), and it is considered a dispositional variable with high stability (Antonovsky 1987; Feldt, Lintula, Suominen, Koskenvuo, Vahtera \& Kiyimäki, 2007). In their research synthesis, Eriksson and Lindström (2007) conclude that the evidence for the relation between sense of coherence and quality of life is strong. Some evidence has already emerged, albeit more than 20 years ago and from a single study, that sense of coherence influences individuals' perceptions of job insecurity (Roskies, LouisGuerin, \& Fournier, 1993). Our study seeks to extend these findings.

Both sense of coherence and locus of control have been shown to be important as they relate either directly to employee health and well-being outcomes, or buffer the effects of job insecurity thereon (Feldt, Kinnunen, \& Mauno, 2000; Spector et al., 2002). These variables are also deserving of further consideration as antecedents to job insecurity. Although scant, some evidence exists that locus of control may be ameliorable by training (Manger, Eikeland, \& Asbjørnsen, 2002; Wolinsky et al., 2010), and may therefore be enhanced in individuals. This might present an important avenue for intervention in enhancing individuals' internal locus of control in order to not only protect them from the damaging consequences of job insecurity specifically, but perhaps also work stress generally. Contrastingly, individuals' sense of coherence presents as being more stable (Antonovsky 1987; Feldt et al. 2007), and the relation it bears to job insecurity is less clear. It could therefore also be of interest to juxtapose these two personality variables in their relation with job insecurity.

\section{Dimensions of job insecurity}

The dimensionality of job insecurity, especially in terms of measurement, has been approached differently by various researchers. The most prominent distinction has been between a general factor (Greenhalgh, 1982; Hartley et al., 1991) and multi-dimensional conceptualisations (Greenhalgh \& Rosenblatt, 1984; Ashford et al., 1989). Meta-analytic results suggest that multi-dimensional and multi-item measures fare better (Keim et al., 2014; Sverke et al., 2002).

Operationally, multi-dimensional conceptualisations consider both cognitive and affective dimensions (De Witte, 2000), but also qualitative and quantitative dimensions (Hellgren, Sverke \& Isaksson, 1999, Scott-Marshall, 2010). Our approach here is aligned with the cognitive/affective 
distinction of De Witte (2000). Given our South African data, it is also one of the job insecurity measures that has been extensively used and validated in South Africa (Pienaar, De Witte, Hellgren, \& Sverke, 2013; Van Wyk \& Pienaar, 2008).

Previous research highlights cognitive job insecurity as an important predictor of both employee health-related and organisational outcomes (De Witte 2000; Hartley et al. 1991; Mauno \& Kinnunen, 2002; Pienaar et al., 2013). Regarding affective job insecurity, the results are less equivocal. Generally it appears to relate more to psychological strain (Huang, Lee, Ashford, Chen \& Ren, 2010; Ito \& Brotheridge, 2007), physical and mental health (Probst, 2003), individuals' impaired self-esteem (Mauno \& Kinnunen, 2002), or emotional exhaustion (Pienaar et al., 2013). Van Zyl, Van Eeden, and Rothmann (2013) showed affective job insecurity to predict organisational detachment and avoidance coping, while cognitive job insecurity predicted low organisational identification, less active coping and less seeking of social support. The picture that seemingly emerges is one that relates affective job insecurity to personal, subjective and individual-level variables. Lee et al. (2006) have specifically called for more investigation into the affective component of job insecurity, as different dimensions of job insecurity may have differential relations to antecedents. Based on these findings, we also opted to investigate the antecedents of cognitive and affective job insecurity separately in our study.

The roles of work locus of control and sense of coherence in predicting job insecurity

Keim et al. (2014) argue that the dominant paradigm in the study of antecedents of job insecurity is the psychological contract theory (Rosseau, 1995). Viewed through this lens, one might think of the experience of job insecurity as a violation of the psychological contract between employee and employer (De Cuyper \& De Witte, 2006, 2008). Not only should individuals with an internal locus of control and high sense of coherence be better able to deal with such a perceived breach; they should also be better equipped to deal with its anticipated consequences.

It must be borne in mind that job insecurity is a subjective perception (De Witte, Van der Elst \& De Cuyper, 2015) and individually determined (i.e. what contributes to perceptions varies across individuals: Lazarus \& Folkman, 1984; Sverke et al., 2002). De Witte et al., (2015) highlight that job insecurity shares features with general job stress, namely a lack of control and of predictability. From the earliest works on job insecurity, locus of control was cited as a possibly important antecedent to job insecurity as an indication of the individual's perception of control (Ashford et al., 1989). Aligned to the idea that job insecurity embodies a lack of control and of predictability, the dimensions of sense of coherence, conceptualised as consisting of comprehensibility, manageability, and meaningfulness (Antonovsky, 1987; 1993), are in sharp contrast. It seems fair to argue that someone who holds low perceptions of manageability should also feel that things are not under control. Similarly, in order to predict, one should also be able to manage, and lacking meaning may feed uncertainty. Mauno, Feldt, Tolvanen, Hyvönen, and Kinnunen (2011) have illustrated that individuals with a low sense of coherence experienced greater risk for reporting career disruptions when measured 7 years later. It would seem logical to deduce that career disruptions had been preceded by periods of perceived job insecurity. Feldt, Leskinen, and Kinnunen (2005) have also shown that employees who were laid off or had become unemployed showed subsequently lowered sense of coherence. Again, if such job loss is detrimental to individuals' sense of coherence, it could follow suit that the perception of job insecurity might also have this effect.

Since the relation between job insecurity, and particularly sub-dimensions thereof (i.e. cognitive and affective job insecurity), work locus of control and sense of coherence have not received much attention to date, the present study set out to investigate these relations. Specifically, we endeavoured to investigate the antecedent relation of work locus of control and sense of coherence to employees' perceptions of job insecurity, while controlling for gender, age and level of education. The role of locus of control is clearer and more thoroughly established, compared to that of sense of coherence. Therefore it is also of interest to comparatively investigate the power of these two personality antecedents when explaining perceptions of job insecurity. Regarding job insecurity itself, the multi-dimensional approach of studying both cognitive and affective job insecurity also appears worthwhile, although expectations regarding the different dimensions and personality are not well informed by current literature.

\section{Research aims}

Based on the above literature review, the aims of this research are to:

- Investigate the relationship between biographical variables, sense of coherence, work locus of control, and cognitive and affective dimensions of job insecurity.

- Investigate the predictive ability of sense of coherence and work locus of control on cognitive and affective job insecurity, after controlling for biographical variables.

- Compare the predictive ability (i.e. variance explained) of sense of coherence and work locus of control in terms of cognitive and affective job insecurity.

\section{Method}

\section{Design/approach}

Data were gathered by means of various anonymous surveys and as part of various postgraduate-level studies at NorthWest University between 2003 and 2006 (refer to Van Wyk \& Pienaar, 2008, for a list). These studies formed part of a larger research project with the aim of investigating the measurement, antecedents and consequences of job insecurity across organisational settings in South Africa. Most recently, a thorough analysis of the validity of the job insecurity measure of De Witte (2000), used in these studies, was published (Pienaar et al., 2013). In 3 investigations from 
those described above, data on participants' work locus of control and sense of coherence was also collected. In all surveys, information was gathered on various items of biographical interest.

\section{Participants}

Data were presented for three samples of employed South African individuals. They hail from the petro-chemical industry $(n=499)$, and two separate financial institutions $(n=146 ; n=73)$. The biographical characteristics of the combined sample are reported in Table 1 . Since we aggregate data from different surveys, each with its specific questions on biographical characteristics, data for some biographical characteristics are missing in some surveys, and present as missing data. Our sample for analyses is mostly males $(64.1 \%)$, largely older than 35 years $(67.5 \%)$, and more than half have attained some post-high school level of education $(56.1 \%)$.

Table 1: Biographical characteristics of the Participants $(\mathrm{N}=718)$

\begin{tabular}{l|l|c|c}
\hline & & Frequency & Percentage \\
\hline \multirow{4}{*}{ Gender } & Male & 460 & 64.1 \\
\cline { 2 - 4 } & Female & 242 & 33.7 \\
\cline { 2 - 4 } & Total & 702 & 97.8 \\
\cline { 2 - 4 } & Missing & 16 & 2.2 \\
\hline \multirow{4}{*}{ Age } & Below 35 years of age & 229 & 32.1 \\
\cline { 2 - 4 } & $\begin{array}{l}\text { Between 35 and 45 years } \\
\text { of age }\end{array}$ & 261 & 36.4 \\
\cline { 2 - 4 } education & $\begin{array}{l}\text { Equal to and older than 46 } \\
\text { years }\end{array}$ & 223 & 31.1 \\
\cline { 2 - 4 } & Total & 713 & 99.3 \\
\cline { 2 - 4 } & Missing & 5 & .7 \\
\cline { 2 - 4 } & High School or less & 297 & 41.4 \\
\cline { 2 - 4 } & $\begin{array}{l}\text { Uiploma or Certificate } \\
\text { qualification }\end{array}$ & 2186 & 25.9 \\
\cline { 2 - 4 } & Total & 700 & 30.2 \\
\cline { 2 - 4 } & Missing & 18 & 2.5 \\
\hline
\end{tabular}

\section{Measuring instruments}

Job insecurity. This dimension was assessed with a shorter version of the measure of job insecurity originally devised by De Witte (2000). This 8-item short-form scale distinguishes between cognitive ( 4 items; example item: 'I think I will be able to continue working here') and affective job insecurity (4 items; example item: 'I fear that I might get fired'), a finding that was corroborated after performing a principal components analysis in this study. These items are rated on a 5-point scale ranging from 1 (Disagree strongly) to 5 (Agree strongly). Positively phrased items are reverse coded so that a high score indicates a high level of insecurity. The reliability of the two sub-dimensions of this scale in South Africa has previously been established (cognitive job insecurity: $\alpha=0.80$; affective job insecurity: $\alpha=0.84$ - Pienaar et al., 2013).

Work locus of control (WLOC) was measured by 16 items, from the scale developed by Spector (1988). This scale was subjected to principal components analysis, and a single factor was extracted. Only one item ('Getting the job you want is mostly a matter of luck') failed to present an adequate loading (i.e. < 0.30, Costello \& Osborne, 2005) and was removed from the final latent variable created. The scale applied in this investigation was 1 (Disagree very much) to 5 (Agree very much), and presented with a Cronbach alpha coefficient of 0.87 . This scale has been used in previous South African research with satisfactory results (Bosman, Buitendach, \& Rothmann, 2005).

The construct Sense of coherence (SOC) was measured with the 29-item scale originally conceptualised and developed by Antonovsky (1979, 1987). The items are presented as statements rated on a 7-point semantic differential scale, presenting positive and negative endpoints. The scale was again subjected to factor analysis. Five items failed to present with sufficient loadings from a single underlying factor and were removed from the final created latent variable ('In the past, when you had to do something which depended upon co-operation with others, did you have the feeling that: Surely wouldn't get done - Surely would get done', 'In the past ten years your life has been: Full of changes without you knowing what will happen next - Completely consistent and clear', 'Most of the things you do in the future will probably be: Completely fascinating - Deadly boring', 'Your life in the future will probably be: Full of changes without knowing what will happen next - Completely consistent and clear', and 'Many people - even those with a strong character sometimes feel like losers in certain situations. How often have you felt this way in the past? Never - Very often'). The factor was reliable, with a Cronbach alpha coefficient of 0.88 , and has been extensively used in South Africa (Strümpfer \& De Bruin, 2009).

Biographical variables. We specifically controlled for gender, age, and level of education in participants' experience of job insecurity. This information is presented and tested as dummy variables. Unfortunately, a measure of ethnicity or cultural group was not present in all data sets (and specifically in the biggest one), and could therefore not be controlled for.

\section{Statistical analyses}

As the measurement properties of the work locus of control and sense of coherence scales in this sample were unknown, the properties of all scales were established by means of exploratory factor analysis. Initially, principal components analysis of the total data set indicated four underlying factors, suggesting the factors of cognitive and affective job insecurity, work locus of control and sense of coherence. In both the latter cases, analysis of only the relevant items also indicated a uni-dimensional solution. To investigate the predictive ability of the two personality variables in terms of the cognitive and affective dimensions of job insecurity, we made use of regression. In the first model, we entered only the biographical dummy variables to control for their effect. The use of dummy variables allows the researcher to compare separate groups or levels of a variable to a base category (Field, 2009). In the analyses, females, older individuals (35 
- 45 years of age; 46 years old and older), and individuals with a higher level of education (post-high school certificate or diploma and university level of education), are contrasted with males, younger individuals (under 35 years of age), and those with lower levels of education (high school or lower). In the second model, we entered the factor scores of employees on the work locus of control and sense of coherence factors. We opted for factor scores to represent each individual's relative placement on the independent variable of interest (DiStefano, Zhu, Mîndrilă, 2009). As such, the use of factor scores allows for the control of different variances of different variables, and is an expression of the unique relationship between variables and factors that accounts for the relationships between pairs of variables (Field, 2009).

\section{Results}

In light of our first research aim, i.e. to investigate the relationship between biographical, independent (e.g. personality: work locus of control and sense of coherence) and dependant (e.g. both dimensions of job insecurity: affective and cognitive) variables, the correlations are considered in Table 2 below.

Table 2: Descriptive statistics and bivariate correlations

\begin{tabular}{|c|c|c|c|c|c|c|c|c|c|c|}
\hline & Mean & SD & Female & $35-45$ & $\begin{array}{l}46 \text { and } \\
\text { older }\end{array}$ & $\begin{array}{l}\text { Certificate } \\
\text { or diploma }\end{array}$ & $\begin{array}{l}\text { University } \\
\text { level }\end{array}$ & \begin{tabular}{|l|} 
Cognitive \\
JI \\
\end{tabular} & \begin{tabular}{|l|} 
Affective \\
JI \\
\end{tabular} & WLOCs \\
\hline 1. $\quad$ Female & & & & & & & & & & \\
\hline 2. $35-45$ & & & $-.15^{* *}$ & & & & & & & \\
\hline 3. 46 and older & & & $-.15^{* *}$ & $.47^{* *}$ & & & & & & \\
\hline $\begin{array}{ll}4 . & \begin{array}{l}\text { Certificate or } \\
\text { diploma }\end{array} \\
\end{array}$ & & & $.14^{* *}$ & $-.09^{*}$ & $-.13^{* *}$ & & & & & \\
\hline 5. University level & & & $.14^{* *}$ & -.05 & $-.08^{*}$ & $.58^{* *}$ & & & & \\
\hline $\begin{array}{ll}6 . & \text { Cognitive JI } \\
\end{array}$ & 2.57 & .91 & -.02 & -.02 & $-.10^{* *}$ & .07 & .06 & & & \\
\hline 7. $\quad$ Affective JI & 2.54 & .84 & $-.08^{*}$ & .04 & -.04 & $-.16^{* *}$ & $-.12^{* *}$ & $.54^{* *}$ & & \\
\hline 8. $\quad$ WLOC & 0 & 1 & .04 & $.08^{*}$ & .06 & $.19^{* *}$ & $.22^{* * *}$ & $-.28^{* *}$ & $-.33^{* *}$ & \\
\hline 9. $\quad$ SOC & 0 & 1 & -.03 & $.09^{*}$ & $.10^{*}$ & $.19^{* *}$ & $.13^{* *}$ & $-.36^{* *}$ & $-.38^{* *}$ & $.45^{* *}$ \\
\hline
\end{tabular}

*. Correlation is significant at the 0.05 level (2-tailed). **. Correlation is significant at the 0.01 level (2-tailed). JI $=$ job insecurity. WLOC $=$ work locus of control. SOC $=$ sense of coherence.

Our correlations were in the expected directions. In this sample, females were significantly younger and better educated compared to males that were older and less educated. The older age categories were also less educated compared to the youngest group. In terms of our variables of interest, it is seen that being in the oldest category is associated with statistically significantly less cognitive job insecurity, while being in the middle age category (35-45) is associated with higher WLOC and SOC compared to the younger group (under 35 y.o.a). Being in the oldest age group also has a stronger association with SOC than being in the youngest group. Being better educated relates negatively to affective job insecurity, and positively to both personality variables. The relation between cognitive and affective dimensions of job insecurity and the personality variables is significant and negative, while they in turn relate positively and significantly to each other.

To investigate the predictive ability of our personality variables with regard to job insecurity (e.g. second aim), separate regressions for cognitive and affective job insecurity were calculated. For all regressions, biographical variables were entered first, followed by WLOC and SOC. This is reported in Table 3.
Table 3: Regression analyses with cognitive and affective job insecurity as outcomes, biographical variables as controls and personality factors as predictors (standardized regression coefficients)

\begin{tabular}{l|c|c}
\hline & $\begin{array}{l}\text { Cognitive job } \\
\text { insecurity }\end{array}$ & $\begin{array}{l}\text { Affective job } \\
\text { insecurity }\end{array}$ \\
\hline Control variables & & \\
\hline Female & -.05 & -.05 \\
\hline $35-45$ & .08 & .08 \\
\hline 46 and older & -.08 & -.03 \\
\hline Certificate or diploma & .11 & -.07 \\
\hline University level & .09 & .03 \\
\hline Main effects & & \\
\hline Work locus of control & $-.21^{*}$ & $-.19^{*}$ \\
\hline Sense of coherence & $-.31^{*}$ & $-.30^{*}$ \\
\hline$R^{2}$ & .20 & .20 \\
\hline$\Delta R^{2}$ & .18 & .17 \\
\hline$* p<0.001$ & \multicolumn{2}{|l}{}
\end{tabular}

It is seen from the results reported in Table 3 that with all variables considered, none of the control variables were statistically significant. The amount of variance explained by the biographical variables in terms of cognitive and affective job insecurity is small (2-3\%). However, consideration of the work locus of control and sense of coherence factors show that they account for a substantial part in the variance in job insecurity, and both were statistically significant. In consideration of our third research aim and while comparing their beta-values, it is also seen that those of sense of coherence are larger than those of work locus of control. Also of interest is that this pattern holds across both dimensions of 
job insecurity. For both cognitive and affective job insecurity, SOC appeared to be more important, consistently explaining $4 \%$ more of the variance, than work locus of control, and for both dimensions of job insecurity. In other words, sense of coherence explained $11 \%$ of the variance in both cognitive and affective job insecurity, while work locus of control explained the remaining variance.

\section{Discussion}

The aims of this study were to investigate the relation between the cognitive and affective dimensions of job insecurity, and a well-known (locus of control) and less wellknown (sense of coherence) antecedent of job insecurity. Additionally, it was also of interest to investigate the predictive ability of the personality variables in terms of cognitive and affective job insecurity, while also controlling for the basic biographical factors of gender, age and level of education. Finally, we were interested in comparing the contributions of locus of control and sense of coherence in terms of explained variance in job insecurity.

Particularly in terms of the noted last research aim, our results are surprising. It emerged that sense of coherence played a stronger role in the prediction of job insecurity, compared to work locus of control. The beta-coefficients from our regression analysis suggest that sense of coherence may be a stronger antecedent of both cognitive and affective job insecurity, than is work locus of control. Examination of the correlations also indicates that the relation between sense of coherence and both dimensions of job insecurity is stronger than that between work locus of control and job insecurity dimensions. This difference in relations is especially pronounced for affective job insecurity, and somewhat less so for cognitive job insecurity. Although it may be presumptuous to suggest that sense of coherence is an important variable that has been overlooked in the study of personality antecedents of job insecurity, our finding definitely warrants further investigation and requires replication. However, it is plausible that sense of coherence plays a stronger role, perhaps due to its apparently greater stability as a personality construct (Antonovsky 1987; Feldt et al. 2007), than does locus of control (Manger et al., 2002; Wolinsky et al., 2010). Our results regarding work locus of control are in line with the recent meta-analytic results (Keim et al., 2014) in supporting the important role thereof in the prediction of job insecurity.

Considering our second aim of controlling for the effects of the biographical variables in the prediction of job insecurity, recent findings of Debus et al. (2014) are relevant. Said authors illustrated that person-related variables (specifically including locus of control and negative affectivity) contributed more than double, compared to environmental variables (company performance and type of contract), to a reduction in prediction error in terms of perceived job insecurity. Although we did not investigate environmental

\footnotetext{
${ }^{1}$ It must be noted that there is partial overlap between our sample and theirs (The sample of $n=147$ ).
}

variables in our sample, biographical variables (none of which reached statistical significance), work locus of control and sense of coherence explained $20 \%$ of the variance in both cognitive and affective job insecurity. In their investigation of the effects of core self-evaluations and coping on perceptions of quantitative and qualitative job insecurity, Låstad et al. (2014) found that these variables predicted $7 \%$ of the variance in quantitative, and $11 \%$ of the variance in qualitative job insecurity in a longitudinal analysis. In a much larger sample from financial institutions in South Africa, Bosman et al. (2005) found the addition of work locus of control (additional to demographics) to predict $14 \%$ of the variance in job insecurity ${ }^{1}$. Compared to these previous studies, we explain the highest amount of variance by considering both personality variables. The most important conclusion from our findings is therefore perhaps that both personality variables are important and contribute unique individual variance in the prediction of both cognitive and affective job insecurity. The latter point is also important; our results are consistent across two distinct, although related, dimensions of job insecurity. Although we have only investigated the noted two personality variables (and biographical controls), we don't find differential relations for these different dimensions as previously suggested (Lee et al., 2006). Taken together, these findings highlight that personality is an important antecedent to job insecurity.

In their meta-analysis, Keim et al. (2014) showed an internal locus of control to be significantly negatively related to job insecurity, with a stronger correlation than even role conflict (as well as organisational communication, considering reliability-corrected correlations). In addressing our first research aim, our independent variables of work locus of control and sense of coherence were coded such that an internal locus of control and strong sense of coherence correlated negatively with job insecurity. In terms of locus of control, this result is in line with previous research (Debus et al., 2014; Orpen, 1994; Näswall, Sverke \& Hellgren, 2005). Sense of coherence, for which previous research findings were less clear, performed exceptionally. Our findings highlight that personality variables are indeed important to consider amongst antecedents of job insecurity. Particularly, we have demonstrated that sense of coherence has a role to play beyond work locus of control.

Some limitations of our investigation are noteworthy. We only present South African data, albeit from 3 different organisations and 2 different economic sectors. Although the latter may perhaps enhance the generalisability of our findings in the South African context, precisely this context may limit the generalisability to other parts of the world.

Our biographical data lacked one variable which seems rather pertinent in the South African context, namely 'race', or at least an indicator of ethnic or cultural group. The available data prevented us from controlling for race to see if it had a role to play regarding personality as an antecedent of job insecurity. Although we are confident of the equivalence of 
the measure across South Africa's multi-cultural employees (see Pienaar et al., 2013), we were still not in a position to control for possible group differences. The consequences of this may, however, not be far-reaching, as recent evidence has emerged that although 'non-designated' employees do experience more job insecurity compared to employees from the 'designated' group; this also does not translate into negative organisational consequences, specifically turnover (De Beer, Rothmann, \& Pienaar, 2015).

\section{Recommendations}

Our study, albeit cross-sectional, does indeed suggest that an external work locus of control and weak sense of coherence should be considered as important antecedents to the perception of job insecurity (both cognitive and affective), with the latter personality variable explaining not only additional, but more variance in terms of job insecurity. Kinnunen et al. (2003) have illustrated, for example, that at least regarding self-efficacy and job insecurity, the relation is reciprocal. Future researchers would do well to also investigate the reciprocal relation of work locus of control and sense of coherence with job insecurity in longitudinal data.

Theoretically, these findings would suggest that at least these two, but probably more personality variables, be considered as possible antecedents of job insecurity. Although there is overlap in terms of the locus of control construct, Låstad et al. (2014) have illustrated that core self-evaluation may be one such variable.

The findings do present at least two personality variables which could be considered in assisting employees in managing perceptions of job insecurity. Promoting control and predictability (such as providing opportunities for participation and clear communication (De Witte et al, 2015; Probst, 2005) could abet employees in taking greater personal responsibility, and making a job-insecure position comprehensible, manageable, and still meaningful.

\section{References}

Ameen, E.C., Jackson, C., Pasewark, W.R. \& Strawser, J.R. 1995. 'An empirical investigation of the determinants and consequences of job insecurity and the turnover intentions of academic accountants', Issues in Accounting Education, 10(1): 65 - 82 .

Antonovsky A. 1993. 'The structure and properties of the sense of coherence scale', Social Science and Medicine, 36: 725-733.

Antonovsky, A. 1987. Unraveling the mystery of health: How people manage stress and stay well. San Francisco, CA: JosseyBass.

Ashford, S.J., Lee, C. \& Bobko, P. 1989. 'Content, causes and consequences of job insecurity: A theory-based measure and substantive test', Academy of Management Journal, 32: 803-829.

Bezuidenhout, A., Khunou, G., Mosoetsa, S., Sutherland, K. \& Thoburn, J. 2007. 'Globalisation and poverty: Impacts on households of employment and restructuring in the textiles industry of South Africa', Journal of International Development, 19: 545 565 .

Blackmore, C. \& Kuntz, J.R.C. 2011. 'Antecedents of job insecurity in restructuring organisations: An empirical investigation', New Zealand Journal of Psychology, 40(3): 7 - 18.

Bosman, J., Buitendach, J.H. \& Rothmann, S. 2005. 'Work locus of control and dispositional optimism as antecedents to job insecurity', South African Journal of Industrial Psychology, 31(4): 17 - 23.

Cheng, G.H.L. \& Chan, D.K.S. 2008. 'Who suffers more from job insecurity? A meta-analytic review', Applied Psychology: An International Review, 57: $272-303$.

Costello, A.B. \& Osborne, J.W. 2005. 'Best practices in exploratory factor analysis: Four recommendations for getting the most from your analysis', Practical Assessment, Research and Evaluation, 10(7): 1 - 9 .

De Beer, L.T., Rothmann, Jr., S. \& Pienaar, J. 2015. 'Job insecurity, career opportunities, discrimination and turnover intention in postapartheid South Africa: Examples of informative hypothesis testing,, The International Journal of Human Resource Management, doi: 10.1080/09585192.2015.1020446.

De Cuyper, N. \& De Witte, H. 2006. 'The impact of job insecurity and contract type on attitudes, well-being and behavioural reports: A psychological contract perspective', Journal of Occupational and Organizational Psychology, 79(3): 395-409.

De Cuyper, N. \& De Witte, H. 2008. Job insecurity and employability among temporary workers: A theoretical approach based on the psychological contract. In K. Näswall, J. Hellgren, \& M. Sverke. (Eds.). The individual in the changing working life (pp. 88-107). Cambridge: Cambridge University Press.

De Witte, H. \& Näswall, K. 2003. 'Objective' versus 'Subjective' job insecurity: Consequences of temporary work for job satisfaction and organizational commitment in four European countries', Economic and Industrial Democracy, 24(2): 149-188.

De Witte, H. 2005. 'Job insecurity: Review of the international literature on definitions, prevalence, antecedents and consequences', South African Journal of Industrial Psychology, 31(4): 1 - 6.

De Witte, H. 2000. 'Arbeitsethos en job onzekerheid: Meting en gevolgen voor welzijn, tevredenheid en inzet op het werk' (Work ethic and job insecurity: Assessment and consequences for wellbeing, satisfaction and performance at work). In R. Bouwen, K. De Witte., H. De Witte, and T. Taillieu (Eds.), Van groep tot gemeenschapp (From group to community) (pp. 325-350). Leuven, Belgium: Garant.

De Witte, H., Vander Elst, T. \& De Cuyper, N. 2015. Job insecurity, health and well-being. In J. Vuori, R. Blonk, \& R. H. Price. (Eds.). Sustainable Working Lives: Managing Work Transitions and Health Throughout the Life Course. New York: Springer.

Debus, M.E., König, C.J. \& Kleinmann, M. 2014. 'The building blocks of job insecurity: The impact of environmental and personrelated variables on job insecurity perceptions', Journal of Occupational and Organizational Psychology, 87: 329 - 351.

DiStefano, C., Zhu, M. \& Mîndrilă, D. 2009. 'Understanding and using factor scores: Considerations for the applied researcher', Practical Assessment, Research and Evaluation, 14(20): 1 - 11. 
Eriksson, M. \& Lindström, B. 2007. 'Antonovsky's sense of coherence scale and quality of life: A systematic review', Journal of Epidemiology and Community Health, 61: 938 - 944.

Feldt, T., Kinnunen, U. \& Mauno, S. 2000. 'A mediational model of sense of coherence in the work context: A one-year follow-up study', Journal of Organizational Behavior, 21: 461 - 476.

Feldt, T., Kivimäki, M., Rantala, A., \& Tolvanen, A. 2004. 'Sense of coherence and work characteristics: A cross-lagged structural equation model among managers', Journal of Occupational and Organizational Psychology, 77: 323 - 342.

Feldt, T., Leskinen, E. \& Kinnunen, U. 2005. 'Structural invariance and stability of sense of coherence: A longitudinal analysis of two groups with different employment experiences', Work \& Stress, 19(1): $68-83$.

Feldt, T., Lintula, H., Suominen, S., Koskenvuo, S., Vahtera J. \& Kivimäki M. 2007. 'Structural validity and temporal stability of the 13-item sense of coherence scale: Prospective evidence from the population-based HeSSup study', Quality of Life Research, 16: 483493.

Field, A. 2009. Discovering statistics using SPSS. $3^{\text {rd }}$ edition. London: SAGE.

Forrest, K. 2014. 'Rustenburg's rractured recruitment regime: Who benefits?', African Studies, 73(2): 149-168.

Greenhalgh, L. \& Rosenblatt, Z. 1984. 'Evolution of research on job insecurity', International Studies of Management and Organization, 40(1): $6-19$.

Greenhalgh, L. 1982. 'Maintaining organizational effectiveness during organizational retrenchment', Journal of Applied Behavioral Science, 18: 155 - 170 .

Hartley, J., Jacobson, D., Klandermans, B. \& van Vuuren, T. 1991. 'Job insecurity: Coping with jobs at risk.' London: Sage.

Hellgren, J., Sverke, M. \& Isaksson, K. 1999. 'A two-dimensional approach to job insecurity: Consequences for employee attitudes and well-being', European Journal of Work and Organizational Psychology, 8: 179-195.

Huang, G.-H., Lee, C., Ashford, S., Chen, Z. \& Ren, X. 2010. 'Affective job insecurity. A mediator of cognitive job insecurity and employee outcomes relationships', International Studies of Management and Organizations, 40: 20 - 39.

Ito, J.K. \& Brotheridge, C.M. 2007. 'Exploring the predictors and consequences of job insecurity's components', Journal of Managerial Psychology, 22: 40 - 64 .

Johnston, C.S., de Bruin, G.P., Györkös, C., Geldenhuys, M., Massoudi, K. \& Rossier, J. 2013. 'Sense of coherence and job characteristics in predicting burnout in a South African sample', $S A$ Journal of Industrial Psychology/SA Tydskrif vir Bedryfsielkunde, 39(1), Art. \#1096, 9 pages. http://dx.doi.org/10.4102/ sajip.v39i1.1096

Keim, A.C., Landis, R.S., Pierce, C.A. \& Earnest, D.R. 2014. 'Why do employees worry about their jobs? A meta-analytic review of predictors of job insecurity', Journal of Occupational Health Psychology. [online] URL:http://dx.doi.org/10.1037/a0036743.
Kerr-Phillips, B. \& Thomas, A. 2009. 'Macro and micro challenges for talent retention in South Africa', South African Journal of Human Resource Management, 7(1), Art. \#157, 10 pages.

Kinnunen, U. \& Nätti, J. 1994. 'Job insecurity in Finland: Antecedents and consequences', European Work and Organisational Psychologist, 4(3): 297 - 321.

Kinnunen, U., Feldt, T. \& Mauno, S. 2003. 'Job insecurity and selfesteem: Evidence from cross-lagged relations in a 1-year longitudinal sample', Personality and Individual Differences, 35(3): 617-632.

Kinnunen, U., Mauno, S., Nätti, J. \& Happonen, M. 1999. 'Perceived job insecurity: A longitudinal study among Finnish employees', European Journal of Work and Organizational Psychology, 8: 243-260.

Kritzinger, A., Barrientos, S. \& Rossouw, H. 2004. 'Global production and flexible employment in South African horticulture: Experiences of contract workers in fruit exports', Sociologia Ruralis, 44(1): 17 - 39 .

Låstad, L., Berntson, E., Näswall, K. \& Sverke, M. 2014. 'Do core self-evaluations and coping style influence the perception of job insecurity?', European Journal of Work and Organizational Psychology, 23(5): 680-692.

Lazarus, R. \& Folkman, S. 1984. Stress, appraisal and coping. New York: Springer.

Lee, C., Bobko, P. \& Chen, Z.X. 2006. 'Investigation of the multidimensional model of job insecurity in China and the USA', Applied Psychology: An International Review, 55(4): 512 - 540.

Levy, P.E., Cober, R.T. \& Norris-Watts, C. 2004. Specific personality measures. In J. C. Thomas (Ed.). The Handbook of Psychological Assessment, Volume 4: Industrial/Organisational Assessment. John Wiley \& Sons Inc., New York: NY.

Manger, T., Eikeland, O.-J. \& Asbjørnsen, A. 2002. 'Effects of social-cognitive training on students' locus of control', School Psychology International, 23(3): 342 - 354.

Maram, A. \& Miller, K. 1998. 'An empirical assessment of the construct "work locus of control", South African Journal of Industrial Psychology, 24(3), 48 - 51.

Mauno, S. \& Kinnunen, U. 2002. 'Perceived job insecurity among dual-earner couples in Finland: Do its antecedents vary according to gender, economic sector, and the measure used?', Journal of Occupational and Organizational Psychology, 75: 295 - 314.

Mauno, S., Feldt, T., Tolvanen, A., Hyvönen, K. \& Kinnunen, U. 2011. 'Prospective relationship between career disruptions and subjective well-being: Evidence from a three-wave follow-up study among Finnish managers', International Archives of Occupational and Environmental Health, 84: 501 - 512.

Näswall, K., Sverke, M. \& Hellgren, J. 2005. 'The moderating role of personality characteristics on the relationship between job insecurity and strain', Work \& Stress, 19(1): $37-49$.

Orpen C. 1994. 'The effects of self-esteem and personal control on the relationship between job insecurity and psychological wellbeing', Social Behavior and Personality, 22(1), 53 - 56. 
Pienaar, J., De Witte, H., Hellgren, J. \& Sverke, M. 2013. 'The cognitive/affective distinction of job insecurity: Validation and differential relations', Southern African Business Review, 17: 1-22.

Probst, T.M. 2003. 'Development and validation of the job security index and the job security satisfaction scale: A classical test theory and IRT approach', Journal of Occupational and Organizational Psychology, 76: 451-467.

Roskies, E., Louis-Guerin, C. \& Fournier, C. 1993. 'Coping with job insecurity: How does personality make a difference?', Journal of Organizational Behavior, 14(7): 617 - 630 .

Rotter, J.B. 1966. 'Generalized expectancies for internal versus external control of reinforcement', Political Monographs, 80(609).

Rousseau, D.M. 1995. Psychological contracts in organizations: Understanding written and unwritten agreements. Thousand Oaks, CA: Sage.

Scott-Marshall, H. 2010. 'The social patterning of work-related insecurity and its health consequences', Social Indicators Research, 96, 313 - 337.

Spector, P.E. 1988. 'Development of the work locus of control scale', Journal of Occupational Psychology, 61: 335-340.

Spector, P.E., Cooper, C.L., Sanchez, J.I., O'Driscoll, M., Sparks, K., Bernin, P., Büssing, A., Dewe, P., Hart, P., Lu, L., Miller, K., Renault de Moraes, L., Ostrognay, G.M., Pagon, M., Pitariu, H. D., Poelmans, S.A.Y., Radhakrishnan, P., Russinova, V., Salamatov, V., Salgado, J.F., Shima, S., Siu, O.-L., Stora, J.B., Teichmann, M., Theorell, T., Vlerick, P., Westman, M., Widerszal-Bazyl, M., Wong, P.T.P. \& Yu, S. 2002. 'Locus of control and well-being at work: How generalizable are western findings?', The Academy of Management Journal, 45(2), 453 - 466.

Spector, P.E., Zapf, D., Chen, P.Y. \& Frese, M. 2000. 'Why negative affectivity should not be controlled in job stress research: Don't throw out the baby with the bath water', Journal of Organizational Behavior, 21: 79 - 95.

Strümpfer, D.J.W. \& De Bruin, G.P. 2009. 'Antonovsky's sense of coherence and job satisfaction: Meta-analyses of South African data', South African Journal of Industrial Psychology, 35(1), Art. \#767, 3 pages.

Sverke, M., Hellgren, J. \& Näswall, K. 2002. 'No security: A metaanalysis and review of job insecurity and its consequences', Journal of Occupational Health Psychology, 7: 242 - 264.

Tong, J. \& Wang, L. 2012. 'Work locus of control and its relationship to stress perception, related affections, attitudes and behaviours from a domain-specific perspective', Stress and Health, 28: $202-210$.

Van Wyk, M. \& Pienaar, J. 2008. 'Towards a research agenda for job insecurity in South Africa', Southern African Business Review, 12(2): 49-86.

Van Zyl, L., van Eeden, C. \& Rothmann, S. (2013). 'Job insecurity and the emotional and behavioural consequences thereof', South African Journal of Business Management, 44(1): 75 - 86.

Wang, Q., Bowling, N.A. \& Eschleman, K.J. 2010. 'A meta-analytic examination of work and general locus of control', Journal of Applied Psychology, 95(4): 761 - 768.
Wolinsky F.D., Van der Weg, M.W., Martin, R., Unverzagt, F.W., Willis, S.L., Marsiske, M., Rebok, G.W., Morris, J.N., Ball, K.K. \& Tennstedt, S.L. 2010. 'Does cognitive training improve internal locus of control among older adults?', The Journals of Gerontology, Psychological Sciences and Social Sciences: Series B, 65(5): $591-$ 598. 